\title{
Intangible Cultural Heritage Museum in The Heart Of Turkey
}

\author{
Beyza Adıgüzel, Ayşe Selin Dülger*
}

\begin{abstract}
The intangible cultural heritage (ICH), which is defined as practices, representations, narratives, knowledge, skills and related tools, materials and cultural places that communities, groups, individuals define as part of their cultural heritage, is transferred via the ways including generational narratives, arts and traditions. In the scope of the research, it's aimed to examine the ways of publicity, protection and transfer of the listed values. In order to reach this aim, Intangible Cultural Heritage Museum in Ankara was selected as the research area.

In this research, Turkey's ICH, including the ones in UNESCO list and ICH of Ankara, promotion and transmission quality have been revealed within the services and activities offered in the museum. Firstly, a list of ICH created, listed ICH were broached to museum manager and provide him to choose which of them were exhibited by their museum. In the light of the obtained data, in-depth interviews with founders were conducted to get detailed information about ICH can be seen in the museum, the achievement of the aims of the museum and the objectives set by the organizers.
\end{abstract}

Anahtar Kelimeler: UNESCO, Intangible Cultural Heritage Museum, Cultural values of Ankara

\section{Türkiye'nin Kalbinde Somut Olmayan Kültürel Miras Müzesi ÖZET}

Toplulukların, grupların ve hatta bireylerin kültürel mirasının bir parçası olarak tanımladıkları uygulamalar, temsiller, anlatılar, bilgi, beceri ve tüm bunlarla ilgili araç gereçler ve kültürel mekanlar olarak tanımlanan Somut Olmayan Kültürel Miras, kuşaksal anlatılar, sanatlar ve gelenekler gibi yollarla aktarllır. Araştırma kapsamında, listelenen değerlerin tanıtım, koruma ve aktarım yollarının incelenmesi amaçlanmıştır. Bu amaca ulaşmak için Ankara'da Somut Olmayan Kültürel Miras Müzesi araştırma alanı olarak seçilmiştir.

Bu araştırmada, UNESCO listesinde yer alan ve Ankara'nın Somut Olmayan Kültürel Miras unsurlarını kapsayan Türkiye'nin Somut Olmayan Kültürel Mirası'nın, müzede sunulan hizmetler ve faaliyetler kapsamında tanıtım ve aktarım özellikleri açıklanmıştır. İlk olarak, Somut Olmayan Kültürel Miras unsurlarının listesi oluşturuldu, oluşturulan liste müze müdürüne sunuldu ve hangi unsurların müzede sergileneceği konusunda bir seçim yapması sağlanmıştır. Elde edilen veriler ışı̆̆ında, müzede sergilenen Somut Olmayan Kültürel Miras, müzenin idareciler tarafindan belirlenen hedef ve amaçlarına ulaşma becerisi hakkında detaylı bilgi almak için müzenin kurucuları ile derinlemesine görüşmeler gerçekleştirilmiştir.

Keywords: UNESCO, Somut Olmayan Kültürel Miras Müzesi, Ankara'nın Kültürel Değerleri

Doi: http://dx.doi.org/10.31822/jomat.424497

* Corresponding Author Article History: Submitted:17.05.2018-Accepted:25.06.2018

Research Paper

Beyza Adıgüzel: Araş. Gör., Hacı Bayram Veli Üniversitesi Turizm Fakültesi, Email: byzhtrnz@gmail.com, Orcid id: 0000-0002-2932-1671 Ayșe Selin Dülger: $\begin{aligned} & \text { Araş. Gör., Hacı Bayram Veli Üniversitesi Turizm Fakültesi, Email: ayseselindulger@gazi.edu.tr, Orcid id: 0000-0001-8897- } \\ & \text { O13X }\end{aligned}$ 


\section{INTRODUCTION}

In recent years, the topic of cultural heritage has gained a great importance in almost every part of the world. The intangible cultural heritage, which is a kind of cultural heritage, is also a very important subject, including the traditions, customs, values of the past. The intangible cultural heritage also has a very important place in terms of protecting these values and transferring them to the future generations.

Within the scope of this research, both UNESCO intangible cultural heritage elements of Turkey and unique cultural values of Ankara are examined within museum studies. Ankara Intangible Cultural Heritage Museum, operating with an aim of promotion and transmission of both local culture of Ankara and intangible cultural heritage of Turkey, is selected as research area. Getting the detailed information about the museum and providing diversification, both documentation, observation and interview with the manager are accepted as research methodology. Findings are reported under 4 titles including preparation process, transmission ways of intangible cultural heritage in the museum, control and efficiency, sustainability.

\section{LITERATURE REVIEW}

\subsection{Culture}

There are many different views on culture. The culture is a unique concept to social sciences. Human is a cultural entity in essence. In 1952, Alfred Kroeber and Clyde Kluckhohn presented 164 different definitions of culture gathered from various scientific and popular sources (Oguz, 2011: 125). In the end of 18th century and in the first half of the 19th century, a few words that today have an important place, have begun to be used for the first time in common English language, and these words gained new and important meanings in time (Williams, 2015). The conceptual roots of the concept extended deeper through the writings of John Locke's Essay on the Understanding of Human (1690) and the writings of Ibn Khaldun, the Arab historian of the nineteenth century (Muller, 2005: 1).

One of the most important traits that distinguishes human beings from others is that it is a cultural being and its culture makes sense of its existence. Every society has different tools to solve the problems that individuals face and to satisfy their needs. These tools vary according to the environmental conditions and the relationships between people. According to Güvenç (1996: 102) from the simplest to the most advanced, we encounter a common phenomenon called culture in every kind of human community (as cited in Duran, 2011: 292).

Culture meant primarily a "natural growth trend" or a "human education process." It was then used in the 19th century as "intellectual development". The 3rd meaning of culture is "the general body of art". The 4th meaning is "all life style, material, intellectual and spiritual" (Williams, 2015).

According to the definition of culture in the Final Declaration of the Conference of World Cultural Policies organized by UNESCO, "culture in its broadest sense is a whole, composed not only a combination of science and literature, but also of distinctive material, spiritual, mental and emotional characteristics that define a society, at the same time it is a phenomenon that includes life forms, human fundamental rights, values, traditions and beliefs" (UNESCO, 1982).

\subsection{Cultural Heritage}

Merryman (1986) suggested that "two ways of thinking about cultural heritage" existed. The first one is a nationalist way seeing the nation's cultural heritage as a part of nation. The second one is a cosmopolitan way promoting the broadest access and circulation to provide cultural understanding 
between different nations, who attach importance to cultural existence as a heritage of mankind (Borelli and Lenzerini, 2012: 3).

Cultural heritage is an important concept for humanity. Hereduc (2005) defines cultural heritage as "the works and expressions of human communication and behaviors that we inherited from our ancestors and we chose to protect for our individual and societal significance" (as cited in Dönmez and Yeşilbursa, 2014: 426). According to Aslan and Ardemagni (2006), cultural heritage is "the creative expression of a society that exist or lived in the past." Also, It tells about the successes, beliefs and traditions of a country and its people (as cited in Dönmez and Yeşilbursa, 2014: 426). As sum, cultural heritage is one of the ways in which humanity transform their unique values and/or products.

Cultural heritage is divided into tangible and intangible cultural heritage. Tangible cultural heritage includes natural and cultural assets in terms of the definitions made. The tangible cultural heritage includes all of the material cultural values such as historic cities, buildings, archeological sites, cultural landscapes, or portable and immovable cultural assets. Tangible cultural heritage assets are diverse, ranging from an insignificant wealth to a broad existence (Du Cros and McKercher, 2014: 66).

Intangible cultural heritage includes languages, religions, traditions, customs, oral products of anonymous folk literature, spectator games, rituals, myths and so on. Today, the protection of this cultural heritage has become, not only individual but also a national and an international issue (Artun, 2004: 147). Herewith, there are international foundations trying to protect them. For example, "Convention for the Protection of Intangible Cultural Heritage", established in 1972 to make important decisions to protect intangible cultural heritage, starting from the Convention for the Protection of Natural and Cultural World Heritage, is based on the principle of "protecting intangible cultural heritage" (UNESCO, 2013).

The Convention for the Safeguarding of Intangible Cultural Heritage was passed by the 32nd UNESCO General Conference held on 29th September-17th October in 2003, in Paris (unesco.org) with the awareness of the need to raise awareness about cultural manifestations and expressions that countries would have no need of legal or programmatic framework to protect them until then.

The Convention was unanimously adopted in the session of the Grand National Assembly on $19^{\text {th }}$ of January, 2006. "Law on the Approval of the Convention for the Protection of the Intangible Cultural Heritage" (No. 5448) was promulgated in the 26056 numbered Official Gazette on January 21, 2006. Accession process of Turkey is completed on March 27, 2006. (unesco.org.tr)

Within the context of the Convention for the Protection of Intangible Cultural Heritage, in order to promote cultural diversity by providing awareness of the importance of intangible cultural heritage, two basic lists are being prepared: " the Representative List of the Intangible Cultural Heritage of Humanity" and " the List of Intangible Cultural Heritage in Need of Urgent Safeguarding" (aregem.kulturturizm.gov.tr). Turkey has cultural heritage elements in both of these lists.

\section{INTANGIBLE CULTURAL HERITAGE IN TURKEY}

Totally, there are 470 elements corresponding to 117 countries. As seen in Table 1, Turkey has had 15 intangible cultural heritage on the Representative List of the Intangible Cultural Heritage of Humanity since 2008; while Whisled Language is added to the List of Intangible Cultural Heritage in Need of Urgent Safeguarding in December, 2017 (ich.unesco.org). 
Table 1 : Listed Intangible Cultural Heritage of Turkey

\begin{tabular}{|l|l|l|}
\hline Year & Listed Intangible Cultural Heritage & Listed Type \\
\hline 2008 & Art of Meddah, Public Storytellers & Representative List \\
\hline 2008 & Mevlevi Sema Ceremony & Representative List \\
\hline 2009 & Aşıklık (Minstrelsy) Tradition & Representative List \\
\hline 2009 & Nevruz & Representative List \\
\hline 2009 & Karagöz & Representative List \\
\hline 2010 & Traditional Sohbet Meetings & Representative List \\
\hline 2010 & Kurkpınar Oil Wrestling Festival & Representative List \\
\hline 2010 & Semah, Alevi-Bektaşi Ritual & Representative List \\
\hline 2011 & Ceremonial Keşkek Tradition & Representative List \\
\hline 2012 & Mesir Paste Festival & Representative List \\
\hline 2013 & Turkish Coffe Culture and Tradition & Representative List \\
\hline 2014 & Ebru: Turkish Art of Marbling & Representative List \\
\hline 2016 & Traditional Craftmanship of Çini Making & Representative List \\
\hline 2016 & Flatbread Making and Sharing Culture: Lavash & Representative List \\
\hline 2017 & Spring Celebration: Hidrellez & Representative List \\
\hline 2017 & Whisled Language & Urgent Safeguarding List \\
\hline
\end{tabular}

(UNESCO; https://ich.unesco.org/en-state/turkey-TR?)

Turkey also has six intangible cultural heritage elements waiting for gaining their place on Representative List (RL) or Urgent Safeguarding List (USL) of UNESCO. As seen on Table 2 Traditional Turkish Archery and Heritage of Dede Qorqud have on-going nomination status to be added to RL while Aşure Ritual, Ahlat Stoneworks Tradition, Nomanic Movement of Serıkeçili Yörüks, Sabantoy-Habantoy all have backlog nomination status. If the nominations will be active again for backlog ones and backlog ones and on-going ones are all accepted; Turkey will have six more intangible cultural heritage on UNESCO lists including Traditional Turkish Archery on RL, Heritage of Dede Qorqud on RL, Aşure Ritual on RL, Ahlat Stoneworks Tradition on USL, Nomanic Movement of Serıkeçili Yörüks on USL, Sabantoy, Habantoy on USL.

Table 2 :On-going and Backlog Nominations of Turkey

\begin{tabular}{|l|l|l|l|}
\hline Year & Intangible Cultural Heritage & Status & List Type \\
\hline 2019 & Traditional Turkish Archery & On-going Nomination & Representative List \\
\hline 2018 & Heritage of Dede Qorqud & On-going Nomination & Representative List \\
\hline 2012 & Aşure Ritual & Backlog Nomination & Representative List \\
\hline 2012 & Ahlat Stoneworks Tradition & Backlog Nomination & Urgent Safeguarding List \\
\hline 2012 & $\begin{array}{l}\text { Nomanic Movement of Serıkeçili } \\
\text { Yörüks }\end{array}$ & Backlog Nomination & Urgent Safeguarding List \\
\hline 2012 & Sabantoy, Habantoy & Backlog Nomination & Urgent Safeguarding List \\
\hline
\end{tabular}

(UNESCO; https://ich.unesco.org/en-state/turkey-TR?)

\subsection{Museum/Museology in Turkey}

A lot of definitions have been made by different researchers on the museum, which was quite old in the past. ICOM has made amendments to the definition of museology from 1946 to 2007. The museum definition of ICOM in 2007 is:

"A museum is a non-profit, permanent institution in the service of society and its development, open to the public, which acquires, conserves, researches, communicates and exhibits the tangible and intangible heritage of humanity and its environment for the purposes of education, study and enjoyment." 
According to İnel (1998: 24) and Genim (1998: 34) The word "museum" used in Turkish language today is derived from Greek word "Mouseion" (as cited in Keles, 2003: 2). In Turkey, museums have emerged as a "contemporary institution" which is a sign of the westernization efforts of the 19th century aiming to "protect" rich historical and cultural heritage of Turkey (Özkasım and Ögel, 2005: 97) Today, there are many museums including 193 affiliated to the Ministry and 239 private museums in Turkey. Intangible Cultural Heritage Museum in Ankara is one of the private museums, it has been operated for 5 years.

\subsection{Intangible Cultural Heritage Museum}

Ankara Intangible Cultural Heritage Museum was established in Hamamönü district in 2013. The objectives of the museum are to mobilize the cultural tourism potential of Ankara, to make field studies to reveal historical and cultural values and to transform the data obtained from these studies into practice models. Among the examples of the cultural heritage applied in the museum, there are the tradition of meddah, the art of marbling and linden printing, shadow and puppet plays, folktales-telling, bride telling lullaby in the bride's room, mangala and children playing jackstones (mmkd.org.tr)

The Ankara Intangible Cultural Heritage Museum, open to visit in 2013, aims to prevent the destruction of these values by exhibiting the historical and cultural values of the city and exhibiting them in the museum or by implementing them (mmkd.org.tr).

The cultural values of Turkey involved in the UNESCO Intangible Cultural Heritage List in Table 1. Totally 15 ICH of Turkey are under protection of UNESCO. Ankara Intangible Cultural Heritage Museum exhibits 7 of them, including Art of Meddah, Âşıklık (Minstrelsy) Tradition, Karagöz, Nawruz, Traditional Meetings, Turkish Coffee Culture and Tradition, Turkish Art of Marbling, continously.

Art of Meddah; defined as art of narrative storytelling in order to entertain audiences with imitation and animation. Those who practice this art are called meddah. Meddah sits on a chair while performing his art, making animations and imitations in his narrative using accessories such as wand and wipes (aregem.kulturturizm.gov.tr).

Âşıklık (Minstrelsy) Tradition; In addition to the cultural memory of Anatolia, the tradition of Âşsklık, an important expression of cultural diversity and richness, It is a multi-faceted art that is shaped by filtering through the experiences of centuries, including narration of poetry, music and story (aregem.kulturturizm.gov.tr).

Karagöz; is a type of shadow game in which the shapes of people, animals or objects depicted are attached to rods and moved on a white screen with light reflected from behind. Karagöz is based on mutual funny dialogues and fights between Karagöz and Hacivat. The laughing feature is provided by wordplays, dances and movements (aregem.kulturturizm.gov.tr).

Nawruz; is widely celebrated on 21st of March in the countries located in the Northern Hemisphere, especially among Turkish and Persian speaking communities. Nevruz, originally coming from the Persian nev ve ruz words, is mentioned in Turkey with names such as Nevruz-i Sultan, Sultan Nevruz, Navriz, Newroz, Noruz, Mart Nine, Day of the Dinosaur, Y1lsırt1, Egg Feast. Nevruz, which means the new day and is also known as the spring festival, carries a Christmas quality for many societies (aregem.kulturturizm.gov.tr).

Traditional Meetings; is the general name of a social solidarity meeting where different groups of men come together in different parts of the year, generally in the winter months and on Thursdays, Fridays or Saturdays. The meeting are held at evening hours, continued until midnight and each member is 
expected to arrive on time and leave on time. Conversations can range from social, political issues to members' economic and health concerns. (aregem.kulturturizm.gov.tr).

Turkish Coffee Culture and Tradition; a traditionally cooked coffee consumed from the beginning of the century. Turkish coffee which has its own taste, smell and preparation method is the main and most special drink of guest hospitality, festivals, engagement ceremonies in Turkey (aregem.kulturturizm.gov.tr).

Turkish Art of Marbling; a traditional art which is made by transferring patterns made of soil paint on paper prepared with special techniques. It is believed that this art originated in Central Asia and was transferred to the west by means of the Silk Road like paper (aregem.kulturturizm.gov.tr).

The museum also contains local cultural values of Ankara. By adding local values of Ankara to the museum, it is aimed to sustain local culture with the ones accepted and protected internationally. Telkâri, rain prayer, trouuseau exhibition, Crocus Day, ferfene, point lace, sinsin games are the ones generally exhibited in the museum.

Telkâri: Filigre, a product of a long and trouble journey from melting metal to making and shaping of the wires, the filling and polishing the internal motifs and reaching the final product to the consumer, is an art of welding soft metals such as gold, silver copper to eachother or to a metal by bending them to form a composition. Filigre tradition, generally seen in Mardin, Eskişehir, Şanlıurfa, Gaziantep, Erzurum, Trabzon, Adana, Bursa, Diyarbakır, Konya, Kahramanmaraş, Antakya, Tokat, Tarsus, Crimea, Macedonia, is also being held in Beypazarı, Ankara.

Rain Prayer: Water and rain which are called as "mercy" by Turks are the source of life and abundance in Turkish society. According to the common belief, rain is the wisdom of Allah and given by Him. Therefore people pray to Allah when it does not rain and when the drought starts. This prayer is not held in closed places, but the outdoors, on high peaks of the towns, villages, even of the cities.

Trouuseau Exhibition: One of the most important traditions in Turkish culture is the tradition of marriage which promotes the unity of young people, strengthens the ties between the families, provides the growth and integrity of the families and the societies. Marriage process consists of asking for girl's hand in marriage, betrothal, engagement, trouuseau exhibition, henna night and wedding stages. Trouuseau exhibition in the wedding tradition includes the bride's home and kitchenware, all kinds of embroidered and laced coverings, towels, makeup materials, jewelries and clothings. The trousseau is prepared with hand labour and accumulated in a long time.

Crocus Day: The transition from winter to spring is celebrated in various applications throughout the world. Crocus Day, which takes its name from a herald of spring, is one of the spring celebrations made in Anatolia and Ankara. On this day, children or young people climb out into the countryside and pick crocuses with a rope called "koschuk" and hang them to a dry bush or tree bracnhes. The children gather together and walk around all the houses in the their villages with the crocus hanged bush on their hands. Then they collect rice material (generally oil, butter and bulgur) from each house by singing poems. Rice is cooked with the collected materials and crocus oats and leaves are added to the rice. Cooked crocus rice is served to whole village and the community celebrate spring while eating the crocus rice and playing games. It is believed that those who eat from Crocus Rice will be luck and have a good fortune whole year.

Ferfene: Ferfene is the name given to an eating customs of Ankara. Ferfene is a food tradition in which everyone includin rich and poor, officier and ordinary citizen, noble and folk meet in the same table and everyone participates in equal amounts. These nights are organized by community leaders, white 
bearded and white-haired wise men, or by lieutenant elders. They are held with the aim of having a conversation, a consultation, an illumination on an important subject.

Point Lace: Oya is a hand-crafted art that makes Anatolian women beautiful; they are small in size but with great meaning. The most important feature of the laces is that women can directly express their feelings and thoughts via them in the environments where they can't express their feelings freely. For example, the laces made with different varieties of green mean that the bride is satisfied with her house and husband while the ones made with yellow mean the bride is unhappy, sluggish and depressed. The point laces made in Nallihan district of Ankara province are different from the ones in other regions because they are made from silk

Sinsin Games: Sinsin game's word meaning is known as "challenge". It is commonly believed that this traditional game played in some parts of Central Anatolia have reached from Turkish Tengri Belief to present. This game, played by the Turks since the days they were in Central Asia, has gained a great importance at those times because including the elements accepted as sacred in Central Asia such as "fire", "soil", "water" and "air". While Sinsin game is based on shamanist beliefs, it has come as a fire game, of which Shamanist character was adapted due to acceptance of Islamic belief, to the present day. The person who is in the game hides behind the smoke and flames of fire and approaches the enemy without being seen and then he/she suddenly attacks his/her enemy, he/she tries to catch and punch him/her.

\section{METHODOLOGY}

The research is handled to investigate the promotion, protection, transmission ways of cultural heritage. Ankara Intangible Cultural Heritage Museum, operating with an aim of promotion and transmission of both local culture of Ankara and intangible cultural heritage of Turkey, is determined as research area.

Firstly Ankara's local culture is researched from govermental documents. For this reason, "Cultural Values of Ankara" documents by Ankara Governorship and Ankara Development Agency; and "Ankara; The Capital of Turkey Where Cultures Are Blended" documents by Ankara Provincial Directorate Of Culture And Tourism are examined and unique cultural values of Ankara are identified. Secondly, intangible cultural values of Turkey is determined from UNESCO. The intangible cultural values exhibited in the museum is examined to execute the promotion and transmission quality of them within services and activities provided by the museum.

Listed intangible cultural values were broached to museum manager and he was asked to choose which ones were exhibited in their museum. He totally chose 19 of them and then explained their transmission ways. Intangible values are to attest via data gained from interview, backdated events and observations.

Interview questions were prepared suitable for the purpose of research aim and to show museum's contribution to cultural sustainability. Interview form is planned as 2-stage. At the first stage, questions related to general features and founding purpose of museums take place. To gain additional information Project outputs are examined. With this aspect, the research shows documentation feature. The second stage contains questions to examine feature of the museum related to containig, reflecting, protecting intangible cultural heritage. Inteview form was controlled by experts to determine the validity. The answers are given directy in the Findings to provide reliability of the research (Marsvasti, 2004; Shenton, 2004).

The interview was had with manager of the museum and activities, real aim of the museum, goal attainment view of the manager was investigated. The interview was had on 8th of February, 2018 between 15.00-16.00; after the interview, observation was made by touring the whole museum after the interview. The research was concluded with data gained from interview, observation and reports of the 
Ankara Intangible Cultural Heritage Museum Project to provide quality and validity via diversification (Patton, 2002; Shenton, 2004).

\section{FINDINGS}

Ankara Intangible Cultural Heritage Museum has been founded within the Project of "Ankara Intangible Cultural Heritage museum" supported by Ankara Development Agency with the cooperation of Gazi University Turkish Folklore Department and Altındağ Municipality. The Museum is operated with the aim of determining, exhibiting, examinning, evaluating, protecting, promoting, being inherited from generation to generation of the values related to intangible cultural heritage, restoring them by using cultural animation and recreation techniques, organizing audiovisual publishings, printing and education activities and organizing exhibitions related to all of these values. It has been open to visit since 28th of May, 2013.

\subsection{Preparation Process}

People, working for the museum which was founded as a result of Ankara Intangible Cultural Heritage Museum Project, have received education and training about deciding the heritage to be included, and the exhibition techniques. Working team has been made of postgraduate students of Gazi University Folklore Department. Museum manager told these about the issue; "The team including about 20 people received education about 'Effective Area Research Techniques'. Within that education, the team was given seminars related to collecting audio-visual materials, taking photographs, etnophorography. As a result of that research, a catalog was created, and that catalog has been the quide of the museum."

The team, receiving education for one month, then visited towns and villages of Ankara and conducted field studies and collected data for 6 months. Within the field study started in March 2012; Bala, Beypazarı, Çamlıdere, Çubuk, Elmadağ, Evren, Gölbaşı, Güdül, Kalecik, Kazan, Kızılcahamam, Nallıhan, Polatlı, Şereflikoçhisar, Keçiören and Akyurt towns of Ankara and villages of these towns were visited and 250 people were interviewed. Field research was implemented to older people in the villages with a purpose to develop implementation models based on traditional knowledge lost due to lack of transmission even if they are still alive in rural areas.

The process of field research was explained as "During the field research, information was gotten from the resource people about their own childhood, birth traditions, weddings, meals, soldiery, sunna, clothes getting older in chests, games played in their childhood, henna nigth songs, village rooms, believes, traditions, festivals, legends and tales. Gathered information was audiovisually recorded, documented in written and archived. The museum composes of exhibiting the data gathered from the field research made by visiting towns and villages of Ankara."

\subsection{Transmission Ways of Cultural Heritage in the Museum}

Unique culture of Ankara and UNESCO Intangible Cultural Heritage are combined in the scope of museum activities because the field research was conducted in Ankara and the museum is in Ankara. These were told related to the issue; "We are telling Ankara tales, so we try to provide to tell something about Ankara via our plays. For example, while acting traditional improvised theatre, Kavuklu and Pişekar are always adopting Hamamönü or Ankara as their neighbourhood. We tend to use Ankara local language in their tales and expressions or add new characters from Ankara and always protect the Ankara emphasis. If the story about Ankara is told out of Ankara, we find a way to include Ankara to the story. We can say that we try to carry the stories to Ankara in some way." 
Table 3: Intangible Cultural Heritage Exhibited In the Museum

\begin{tabular}{|c|c|c|c|}
\hline Type & Application Area & Heritage & Presentation Way \\
\hline \multicolumn{4}{|c|}{ UNESCO Intangible Cultural Heritage Of Turkey } \\
\hline Performance Arts & $\begin{array}{l}\text { Performance Arts } \\
\text { Room }\end{array}$ & Art Of Meddah & Storytelling \\
\hline Performance Arts & $\begin{array}{l}\text { Performance Arts } \\
\text { Room }\end{array}$ & Karagöz & Acting/Performing \\
\hline Oral Narrative Traditions & Festivals & $\begin{array}{ll}\text { Âşıklık } & \text { (Minstrelsy) } \\
\text { Tradition } & \end{array}$ & Event \\
\hline $\begin{array}{l}\text { Community Knowledge, Universe } \\
\text { And Nature }\end{array}$ & Festivals & Nawruz & Celebration \\
\hline Oral Narrative Traditions & $\begin{array}{l}\text { Traditional } \\
\text { Communication Room }\end{array}$ & Traditional Meetings & Event \\
\hline 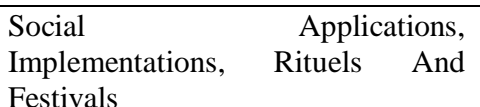 & - & $\begin{array}{l}\text { Turkish Coffee Culture } \\
\text { And Tradition }\end{array}$ & Workshop - Presentation \\
\hline Handicrafts & Workshop & $\begin{array}{l}\text { Art of Marbling: Turkish } \\
\text { Paper Adornment Art }\end{array}$ & $\begin{array}{l}\text { Workshop } \\
\text { Implementation }\end{array}$ \\
\hline \multicolumn{4}{|l|}{ Intangible Cultural Values Of Ankara } \\
\hline $\begin{array}{l}\text { Social } \\
\text { Implementations, } \\
\text { Festivals }\end{array}$ & Festivals & Seğmen Tradition & Performing \\
\hline Handicrafts & Workshop & Filigree Art & Workshop - Presentation \\
\hline- & Building & Ankara Houses & Museum Building \\
\hline $\begin{array}{l}\text { Social } \\
\text { Implementations, } \\
\text { Festivals }\end{array}$ & Festivals & Akhism Ritual & Performing \\
\hline $\begin{array}{l}\text { Social } \\
\text { Implementations, } \\
\text { Festivals }\end{array}$ & Game Room & Jacks & Playing \\
\hline $\begin{array}{l}\text { Social } \\
\text { Implementations, } \\
\text { Festivals }\end{array}$ & Festivals & Ankara Rain Prayer & Event \\
\hline $\begin{array}{l}\text { Social } \\
\text { Implementations, } \\
\text { Festivals }\end{array}$ & Bride Room & Trousseau Exhibition & Presentation \\
\hline $\begin{array}{l}\text { Social } \\
\text { Implementations, } \\
\text { Festivals }\end{array}$ & Festivals & Crocus Day & Event \\
\hline Oral Narrative Traditions & $\begin{array}{l}\text { Traditional } \\
\text { Communication Room }\end{array}$ & Ferfene Tradition & Event \\
\hline $\begin{array}{l}\text { Social } \\
\text { Implementations, } \\
\text { Festivals }\end{array}$ & Game Room & Mangala & Playing \\
\hline Handicrafts & Bride Room & Nallhhan Point Laces & Presentation \\
\hline $\begin{array}{l}\text { Social Applications, } \\
\text { Implementations, Rituels And } \\
\text { Festivals }\end{array}$ & Festivals & Sinsin Games & Performing \\
\hline
\end{tabular}

Ankara Intangible Cultural Heritage Museum has sections in which objects, animations, audiovisuals, information and documents reflecting five parts of intangible cultural heritage. While there are folklore kinds including fabulating, Âş1klık (Minstrelsy) Tradition are in "Oral Narrative Traditions" part of museum. The art of the Meddah, Karagöz, traditional improvised theatre, muppets are all exhibited in "Performance Arts" room. In the part related to "Social Applications, Implementations, Rituels And Festivals", there are implementations taking part in life cycle and the ones coming to life via rituels and belonging to transitional period, food culture and children's plays. In the part of "Community Knowledge, Universe And Nature", 
there are exhibitions in regard to community believes, traditional festivals. Finally, in the part of "Handicrafts", Turkish paper marbling, linden print are taken part and products are being exhibited. Categorized cultural heritage are exhibited in both museum and annual festivals arranged by the museum. The museum has five room parts including performance arts room, bride room, conversation room, play room to exhibit cultural heritage, organize workshops and a backyard for some festivals and rituals."

There is data related to Intangible Cultural Heritage and cultural values of Ankara which are presented in the museum in Table 3.

Different methods are adopted about presentation of cultural heritage in the museum due to differences in visitor types. Because the museum has an aim that "presented products and services are paid attention to have a structure fed by tradition as much as possible", they find traditional solutions to different kinds of visitors. For example they serve via storyteller to children while they tell folktales with serious Meddahs to adults. Meddahs also tell the folktales on special days; "Sometimes, Meddahs help us in storytelling on special days. For example; on the day of ashura, when the Biblical Flood is being told, it isn't so suitable to start to tell the story by saying "Once Upon A Time...". In the situations like these, Meddah start to tell the story by saying "My Rightful Friend".

About the shadow plays; "firstly traditional structure is told and then Karagöz Shadow Plays are performed in performance room". By doing so, both information about traditional structure and reinforcement of information are provided via the performance. Karagöz shadow plays generally tent to be Ankara themed.

Every year, different periods of the year, museum officials "reach Aşıks from Ankara and different part of Turkey and Turkic Republics" and organize events "to make them to understand each other and tell themselves and their cares to us". The manager explained the content with these words; "atma folk songs with bağlama is performed live, by doing so people can experience the performance. They may sometimes turn to "leb-değmez"

"Traditional Meetings", Ferfene Nights, are another value contained by the museum. Traditional meetings, which Meddahs are attended to and folktales are told in, are conducted in the "Communication Room". For January, "A Winter Night" was planned by the museum, however it was postponed due to lack of snow. The situation was told as "This nights mean "wisdom taking nights"; we've dreamed of organizing a winter night in this winter; but unfortunately there wasn't any snowy night in Ankara this year. If we could have, we would have roasted chestnuts and performed "theatrical village plays."

Regarding Nawruz, the museum starts the Nawruz events, which are parallel with UNESCO studyings, with a photography exhibition called as "Nawruz is a flower and biological diversity". After the photography exhibition, every year they celebrate Nevruz and they also play SinSin within the Nawruz celebrations.

Workshops are conducted related to Turkish Coffee in the museum. Within the workshops, "information about history, speciality and making tricks about Turkish Coffee are provided." On these days, events are mentioned to be all about Turkish coffee; "on these days, traditional improvised theatre plays (Orta Oyunu) are changed as Medium Coffee (Orta Kahve); Kavuklu was coffee maker, Pişekar is visitor and İbiş was apprentice".

\footnotetext{
${ }^{1}$ Lebdeğmez is Aşık style poem culture based on the disuse of " $b, \mathrm{~m}, \mathrm{p}, \mathrm{f}, \mathrm{v}$ " during the performance.
} 
The museum has a Game Room for children games such as Jacks, Peg-Top, Mangala. In this room, bygone child-games "are presented regularly. Each game is not only presented, but also played," to teach them to next generations.

Paper Marbling, Linden Print are together from the activities handled regularly in the museum. About the handicrafts, the museum "regularly has workshops related to Paper Marbling, Linden Print. Out of workshop periods, both are applied with."

An example of historical Ankara Houses has been home to Intangible Cultural Heritage Museum since 2013. Thus, both the museum has a authentic environment and an active presentation of Ankara Houses is provided.

Rain Prayer and Crocus Day are combined; they both pick up crocus and then pray for rain because Ankara has a quite continental climate. Preparations for Crocus Day Festivals start one day before the festival; "We go to Karapürçek and pick up crocuses with buckets. While we're picking up, food is being prepared in large cooking-pots at the kitchen for the great festival. During the festival, children knock doors and ask for butter, bulgur; call people to the Festival and sing folk songs. Of course, all is handled in only theatric way." Specialities of the festival and information about it are told to participants. They also "choose the favorite folk song, dressing crocus rice with crocus flowers and eat it. After eating the crocus rice, Crocus Day games are played and sometimes Seymens also attend to our festival and perform their folk dance."

It is also told that museum restocked and enriched with new oral culture values. These were told about the issue; "we had lackings, we restock them; we've built a harvest corner, placed oral culture examples to the rooms (materials, brainteasers etc.)., we've had a change and development for more interaction. As a result of that process, we put some materials, which are the key instruments to explain some folk discourses, to the rooms and backyard". There are cabinet, water jug, höllük in the museum to animate and explain the discourse. For example, water jug is to explain "water jug breaks on the water way" discourse which means "live by the sword die by the sword" in English. "We want people, especially children, understand and know where these discourses come from; so we tell them the story with materials and meanings. Our primary focus is to provide place for cultural heritage via stories. ICH isn't covering only oral culture; so we also had, for example, Pastal which Pişekar hold, also means slapstick, in our performance room; and tell people what it is via stories and muppets of the characters."

\subsection{Control and Efficiency}

One section of the interview is about the development process of the museum. It wouldn't be wrong to claim that veridicality of heritage presented in the museum has been developed in time. "Parts of the museum have been founded as a result of the 5-year-research within a project; rooms were tried to evaluate as workshops under five title while they were disorderly in the beginning."

The museum founded within Gazi University, doesn't have any worry about having profit directly. Accordingly, the main aim of the museum is to present, transmission and protect of cultural heritage. While doing this, even only one person is important to them; "In analogy to theatre, even one person we can reach is significant for us. If someone visits us and we can provide true information about our own cultural heritage, this is enough for us to see ourselves successful."

\subsection{Sustainability}

Fixing the presented heritage within and out of the museum is considerable to provide continuity of the heritage. Although content or presentation techniques change, the same and inclusivist values are presented in rooms, workshops and backyard of the museum consistently. Similarly, the museum pays 
attention to festivals containing cultural values such as Crocus Day, Seimeni, Nawruz, Âşıklık (Minstrelsy) Tradition, Akhism Rituals annually. Gazi University Folklore postgraduate students are encouraged to participate the museum activities to provide continuity for coming years.

\section{RESULTS AND SUGGESSTIONS}

It is possible to say continuity of values presented in the museum has been provided for the rest 5-yearperiod. To provide this, postgraduate students who also specialize on Folklore and were participated in creation process are working in the museum. Museum presents the values in 5 category including "oral narrative traditions", "performance arts", "social applications, implementations, rituels and festivals", "community knowledge, universe and nature", "handicrafts". These 5 category includes totally 19 of Anatolian cultural values.

The museum pays attention to ICH determined by UNESCO to be fed by tradition and brend them with Ankara. Thus, Turkish Coffee, Ankara local language, characters from Ankara are invited to Karagöz plays; Nallihan Point Lace is presented in Bride Room; Hamamönü community is invited to Crocus Day Festivals; Traditional Meetings are held with Ankara community. Similarly, Game Room is organized to present old-time-games and the games are aimed to teach primary school students visiting museum regularly. Also, Performance Art Room is organized as to introduct, display shadow plays and also backyard is used to perform Karagöz or theatrical village plays sometimes.

Nawruz, Akhism Rituals, Âşıklık (Minstrelsy) Tradition are handed down to next generations by presentating and promoting via special events. Within the events, Seimeni and Sinsin game are also taking place as recreational.

In brief, some of cultural heritage is exhibited, promoted and protected with activities within and out of museum. Visitors and community are included to the activities as much as possible to get an interactive process and traditions we can't face in daily life are animated and revived to protect and hand down the next generations. Continuous promotion is provided via these activities. For the long term, it is expected they will affect sustainability of cultural values, heritage.

Promotion of oral culture from intangible cultural heritage to continue in different part of museum is significant for both understanding the discourses correct and learning the depth of the meaning. Transmission of discourses, words, idioms of Turkish language which has been exposed to deformation of foreign language with the effect of globalization, will contribute to protection of the language.

For the future researches, internationally comparative research can be handled to show the exhibition and cultural differences of countries. In addition to this, researchers can handle each kind of cultural values seperately and can provide deeper information about their history, meanings, exhibition ways etc.

\section{REFERENCES}

Ankara Provincial Directorate Of Culture And Tourism. (2013). Ankara; The Capital of Turkey Where Cultures Are Blended. Ankara.

Ankara Governorship and Ankara Development Agency. (2017). Cultural Values of Ankara. Ankara.

Artun, E. (1996). Today Adana Aşıklık Tradition and Aşık Feymani. Adana: Hakan Ofset.

Aslan, Z., and Ardemagni, M. (2006). Introducing Young People to the Protection of Heritage Sites and Historic Cites. 
Borelli, S., Lenzerini, F. (2012) Cultural Heritage, Cultural Rights, Cultural Diversity, New Developments in International Law, Boston.

Dönmez, C., Yeşilbursa, C.C. (2014) The Effect of Cultural Heritage Education on Students' Attitudes toward Tangible Heritage, Elementary Education Online, 13(2), 425-442, 2014.

Cros, D. H., Mckercher, B. (2014) Cultural Tourism, Second Edition, Routledge.

Duran, E. (2011) Tourism Culture and Identity Relationship; Sustainability of Social and Cultural Identity in Tourism, Istanbul Commerce University Journal of Social Sciences Year: 10 Issue: 19 Spring 2011 p.291313.

Genim, Sinan, (1998) "Museum Inspiration" 4th Museum Tradition Seminar Reported, 47-50.

Güvenç, B. (1996). Human and Culture. Remzi Bookstore, 7th Edition, Istanbul.

Hereduc. (2005). Heritage in the classroom: A Practical Manuel For Teachers.

ICOM (International Council of Museums), http://icomturkey.org/tr/icoma-g\%C3\%B6rem\%C3\%BCzenin-tan\%C4\%B1m\%C4\%B1, Date of Access: February 14, 2018.

Inel, B. (1998) "Periodical Works on Art Activities, Conservation and Restoration in the United States of America, Artifacts in the United States, and Exhibition Plans" 4. 24-29.

Keleş, V. (2003). Modern Museum and Turkish Museology, Atatürk University, Journal of Graduate School of Social Sciences, Cilt:2, Number:1-2.

Marvasti, A.B. (2004). Qualitative research in sociology. London: Sage Publications Ltd.

Merryman, J. H., (1986). Two Ways of Thinking About Cultural Property The American Journal of International Law, 80 (4). 831-853.

Ministry of Culture and Tourism General Management of Research and Education, http://aregem.kulturturizm.gov.tr/TR,131527/meddahlik-gelenegi.html, Date of Access: January 27, 2018.

Ministry of Culture and Tourism General Management of Research and Education, http://aregem.kulturturizm.gov.tr/TR,202225/mevlevi-sema-toreni.html, Date of Access: January 27, 2018.

Ministry of Culture and Tourism General Management of Research and Education, http://aregem.kulturturizm.gov.tr/TR,202290/asiklik-gelenegi.html, Date of Access: January $27,2018$.

Ministry of Culture and Tourism General Management of Research and Education, http://aregem.kulturturizm.gov.tr/TR,12744/karagoz.html, Date of Access: January 30, 2018.

Ministry of Culture and Tourism General Management of Research and Education, http://aregem.kulturturizm.gov.tr/TR,159625/nevruz.html, Date of Access: January 31, 2018.

Ministry of Culture and Tourism General Management of Research and Education, http://aregem.kulturturizm.gov.tr/TR,12209/geleneksel-sohbet-toplantilari-insanliginsomut-olmayan-.html, Date of Access: January 31, 2018.

Ministry of Culture and Tourism General Management of Research and Education, http://aregem.kulturturizm.gov.tr/TR,12207/kirkpinar-yagli-gures-festivali-insanliginsomut-olmaya-.html, Date of Access: February 3, 2018. 
Ministry of Culture and Tourism General Management of Research and Education, http://aregem.kulturturizm.gov.tr/TR,132379/mesir-macunu-festival.html, Date of Access: February 3, 2018.

Ministry of Culture and Tourism General Management of Research and Education, http://aregem.kulturturizm.gov.tr/TR,12208/alevi-bektasi-ritueli-semah-insanliginsomut-olmayan--k-.html, Date of Access: February 7, 2018.

Ministry of Culture and Tourism General Management of Research and Education, http://aregem.kulturturizm.gov.tr/TR,202350/toren-keskegi-gelenegi.html, Date of Access: February 7, 2018.

Ministry of Culture and Tourism General Management of Research and Education, http://aregem.kulturturizm.gov.tr/TR,76265/turk-kahvesi-kulturu-ve-gelenegi-unescoinsanligin-somu-.html, Date of Access: February 8, 2018.

Ministry of Culture and Tourism General Management of Research and Education, http://aregem.kulturturizm.gov.tr/TR,126302/turk-kagit-susleme-sanati-ebru-unescotarafindan-oy-bir-.html, Date of Access: February 8, 2018.

Ministry of Culture and Tourism General Management of Research and Education, http://aregem.kulturturizm.gov.tr/TR,159254/cinicilik-sanati.html, Date of Access: February 8,2018

Ministry of Culture and Tourism General Management of Research and Education, http://aregem.kulturturizm.gov.tr/TR,202366/ince-ekmek-yapma-ve-paylasma-kulturulavas-katirma-jupk-.html, Date of Access: February 9, 2018.

Ministry of Culture and Tourism General Management of Research and Education, http://aregem.kulturturizm.gov.tr/TR,12240/unesco-insanligin-somut-olmayan-kulturel-mirasi-temsil-.html, Date of Access: May 4, 2018.

Muller, A. (2005) Concepts of Culture, Art, Politics, Society, Published by the University Calgary Press, Alberta, Canada.

Oğuz E. S. (2010) Cultural Polıcy And Libraries In Turkey 1923-1980, Hacettepe University Social Sciences Institute Department of Information and Document Management, PHD Thesis, Ankara.

Organization of Museum Occupation, http://mmkd.org.tr/ankara-somut-olmayan-kulturel-mirasmuzesi, Date of Access: February 10, 2018.

Özkasım H., Ögel, S. (2005) Development of Museology in Turkey, Journal of İstanbul Technical University Social Sciences, Volume: 2, No: 1, 96-102, December.

Pasinli, A., (2002). Turkey Museums, T. C. Culture Ministry Publications, Ankara.

Patton, M.Q. (2002). Qualitative research \& evaluation methods (3rd ed.). London: Sage Publications, Inc.

Shenton, A. (2004). Strategies for ensuring trustworthiness in qualitative research projects. Education for Information, 22, 63-75.

UNESCO (1982). Mexico City Declaration on Cultural Policies, http://webarchive.unesco.org/20170204034755/http://portal.unesco.org/culture/en/files/ 12762/11295421661mexico_en.pdf/mexico_en.pdf, Date of Access: February 8, 2018. 


UNESCO Intangible Cultural Heritage Specialization

http://unesco.org.tr/dokumanlar/somut_olmayan_km/sokum_bb.pdf, Date of Access: February 3, 2018.

UNESCO (2013). Somut Olmayan Kültürel Mirasın Türkiye Deneyimi http://www.unesco.org.tr/Content_Files/Content/Yayinlar/sokum_deneyimioptimize.pdf, Date of Access: January 29, 2018.

UNESCO (2018). https://ich.unesco.org/en/lists, Date of Access: May 7, 2018.

UNESCO (2017). The Convention for the Safeguarding of Intangible Cultural Heritage.

http://www.unesco.org/new/en/santiago/culture/intangible-heritage/convention-intangiblecultural-heritage, Date of Access: May 16, 2018.

UNESCO (2018). Somut Olmayan Kültürel Miras Listelerinde Türkiye.

http://www.unesco.org.tr/Pages/126/123/UNESCO \%C4\%B0nsanl\%C4\%B1\%C4\%9F\%C4\% B1n-Somut-Olmayan-K\%C3\%BClt\%C3\%BCrel-Miras\%C4\%B1-Temsili-Listesi, Date of Access: May 16, 2018.

UNESCO. Turkey and the 2003 Convention. UNESCO; https://ich.unesco.org/en-state/turkey-TR?, Date of Access: May 16, 2018.

Williams, R. (2015) Culture and Society: Coleridge to Orwell, London. 